\title{
Comment
}

\section{Institutions for getting out of the way}

\author{
RICHARD N. LANGLOIS* \\ Department of Economics, The University of Connecticut, Storrs, CT 06269-1063 USA and Institutions and Political \\ Economy Group, School of Economic and Business Sciences, University of the Witwatersrand, Johannesburg, South \\ Africa
}

\begin{abstract}
In 'Max U versus Humanomics: a Critique of Neoinstitutionalism', Deirdre McCloskey tells us that culture matters - maybe more than do institutions - in explaining the Great Enrichment that some parts of the world have enjoyed over the past 200 years. But it is entrepreneurship, not culture or institutions, that is the proximate cause of economic growth. Entrepreneurship is not a hothouse flower that blooms only in a culture supportive of commercial activity; it is more like kudzu, which grows invasively unless it is cut back by culture and institutions. McCloskey needs to tell us more about the structure of the relationship among culture, institutions, and entrepreneurship, and thus to continue the grand project begun by Schumpeter.
\end{abstract}

In 'Max U versus Humanomics: a Critique of Neoinstitutionalism', McCloskey (2015) makes two arguments against the brand of institutional economics she associates with the likes of North (2005) and Greif (2006) - two arguments that, she ultimate concedes, are in fact separable. ${ }^{1}$ I will be concerned mostly with the second argument, though I will suggest that, viewed from the right angle, the two arguments might not be so separable after all. Before I set off, let me make clear that, even as I take some issues with (or at least spin differently) the essay under examination here, I am big fan of the work of McCloskey. It's some of the most exciting and innovative writing in the social sciences (and humanities!) today.

Both of the arguments in 'Max U' target the Samuelsonian formulation of economics: we explain outcomes as the maximization of rational agents subject to constraints. Although Paul Samuelson did the math, which had already been lurking in the 19th century writings of Jevons and Walras, it may be Robbins (1932) who is the real culprit. No longer should we see economics as about the sources of material wealth, said Robbins; neither should we confine economics

\footnotetext{
*E-mail: richard.langlois@uconn.edu

1 Thanks to Geoff Hodgson and Leshui He for useful comments and discussions. The author is solely responsible for any errors or odd opinions.
} 
to the study of phenomena in the marketplace. Instead, we should see economics as concerned with the problem of unlimited wants in the face of scarce means. This definition of economics slipped into post-war textbooks, notably including that of Samuelson, and many of us now find ourselves constantly trying to hammer the idea of scarcity into the heads of eighteen-year-olds. As indeed well we should: there is no such thing as a free lunch. Yet 'Robbinsian economizing', as Kirzner (1973) calls it, has had two effects, corresponding to McCloskey's two arguments.

One effect of the Robbinsian definition was to set loose among economists the spirit of imperialism. Economics is no longer about material well-being or the mechanisms of the marketplace, so it can be applied anywhere ends cannot be satisfied by the scarce means available. Which is everywhere. I tend to think that this is largely to the good, as it has smacked some hard-headed sense into fields that had been (and indeed remain) dominated by fuzzy Romantic thinking. (I look forward eagerly to McCloskey's new book, where, I hope and expect, Romantics will get their comeuppance. More on this below.) But McCloskey laments what has been lost. In conceiving of all situations as maximization subject to constraint, we miss the subtle and tacit aspects of human interaction that are culture, ethics, and identity.

The second effect of the Robbinsian definition, of course, is that it has made economics static. It's all about the allocation of given means to given ends. The formalism has essentially no mechanism to talk about, let alone explain, what is arguably the most astonishing and significant phenomenon in the social sciences: the 30-to-100-fold (depending on how you count) increase in incomes per capita in Western Europe, its offshoots, and Japan over the last couple of centuries, what McCloskey calls the Great Enrichment.

As McCloskey concedes, however, allowing culture, ethics, and identity back into our theorizing does not make that theorizing dynamic. So what would make our theorizing dynamic? As I think McCloskey would ultimately agree, the answer is (productive) entrepreneurship, what she calls market-tested betterment. Economic growth occurs when people do not merely adjust their existing scarce means but rather seek new means, better ways to adjust means, and maybe even new ends. People experiment, they learn, they improve. (The market-tested part ensures that entrepreneurship makes the pie bigger rather than merely redistributes (or destroys) some slices (Baumol, 1990).)

So the problem for understanding - and, better yet, encouraging - economic growth is to figure out the nature and sources of entrepreneurship. Under one view, entrepreneurship is like a hothouse flower, and it will not blossom without a lot of tender loving care. If you attend a meeting of the International Joseph A. Schumpeter Society, you can hear many papers on 'entrepreneurship policy', which seeks an activist role for government in somehow fomenting entrepreneurship that would not otherwise take place. This is especially popular in Europe, where governments want entrepreneurship, but they only want to do 
more activist policy things, and they don't want to stop doing any of the many policy things that discourage entrepreneurship.

A quite different view was articulated a long time ago by Adam Smith. Dugald Stewart, Smith's first biographer, reports his notes of a lecture by Smith in 1755: 'Little else is requisite to carry a state to the highest degree of opulence from the lowest barbarism, but peace, easy taxes, and a tolerable administration of justice; all the rest being brought about by the natural course of things'. ${ }^{2}$ A wise person once referred to this as 'Adam Smith's deal - leave me alone and I'll make you rich'. ${ }^{3}$ Clearly Smith doesn't mean that growth can take place in the absence of institutions - peace, low taxes, and the administration of justice require institutions. What he really means, I think, is that we shouldn't see entrepreneurship as a hothouse flower. It is more like kudzu: if you don't do something actively to stop it from happening, you'll have as much of it as you can handle. People may not even need a particular culture or set of microinstitutions in order to pursue entrepreneurship. If you get out of their way, people can create endogenously the micro-institutions (and maybe the culture?) they need, in exactly the same way they develop the skills, knowledge, and technology they need to better their conditions. (Of course, as we will see, getting out people's way is ultimately a matter of institutions at the macro level; this indeed is my central point.) So explaining economic growth is a matter of identifying the factors that impede or prevent people from bettering their conditions. Factors like relative prices, climate, geography, and endowments of knowledge can channel entrepreneurship. ${ }^{4}$ But the principal culprits for actually stopping entrepreneurship are culture and institutions. McCloskey is now willing to admit, perhaps reluctantly, that both of these factors can be important. But the point here, and in Bourgeois Dignity (McCloskey, 2010), seems to be that culture is what does the heavy lifting.

Notice again that there is a fine line between hothouse theory and kudzu theory. Is it that, absent a culture that validates commercial activity, people simply won't want to better their conditions? Shades of Polanyi (1944). Or is it that, in any culture that fails to validate commercial activity, people will want to better their conditions but culture will strongly discourage or even prevent them from doing so? This latter is what McCloskey seems to be saying. But this immediately raises questions. Can we imagine a culture that fails to validate commercial activity affirmatively yet also fails to discourage it? In a small society this may be hard to imagine; but as societies become larger, they become more

2 http://oll.libertyfund.org/quote/436, accessed 25, July 2015. Of course, it is an open question whether Smith still held so unvarnished a view later in the Wealth of Nations (Smith, 1976), where he finds a place for public goods and even approves of the Navigation Acts.

3 D. N. McCloskey, 'Capitalism, or Virtue Rewarded', book review of How the West Grew Rich by Nathan Rosenberg and L. E. Birdzell, Jr., The New York Times Book Review, February 9, 1986, p. 18.

4 'The rôle of environmental factors was to sketch out least-cost paths of human action. Ceteris paribus we should expect them to have been followed' (Jones, 2003, p. 228). 
anonymous, more diverse - and arguably more neutral. Could we even imagine a case in which a culture actively frowns on commercial activity yet people still find a way to better their conditions?

It would be difficult to find a culture more hostile to commercial activity, and indeed to bettering one's condition in any manner, than China under Mao. This culture was certainly emanating from the top, but it was effective at the local level. The memoirist Chen (2000) documents the extreme persecution during the Cultural Revolution, from the village itself at the grass roots, of anyone whose family had once been even the pettiest of landowners or shopkeepers. And then suddenly everything changed. The Party decided that wealthy communists were better than poor communists, and the state began the process of getting out of the way. Did the culture - the ethics of what a society honors or dishonors - change that quickly? 'Once someone is corrupted by life in a communist country', says McCloskey, 'it is hard to reset her ethics. She goes on relying on the 'bureau' model of human interaction as against the market' (pp. 21-22). That may have happened in Russia, but it doesn't seem to have happened in China. At the same time, McCloskey makes a point of telling us (p. 12) that culture can often turn on a dime. If this is so, the real cause of change must have come from elsewhere, from a sudden alteration in relative prices or institutions perhaps, with culture adapting not leading.

Chinese people I have spoken with do not see present-day Chinese culture as affirming or honoring of commercial activity. It is a culture of bald-faced pragmatism. We are all socialists (wink, wink), but it's okay to go about bettering our conditions. 'A country achieves the Great Enrichment by allowing improvers to creatively destroy earlier ways of doing things. If the sultan throws the improver off a cliff, the Ottoman Empire will remain poor' (McCloskey, 2015:9). The Red sultans (mostly) stopped throwing improvers off the cliff, and the Chinese Empire is becoming rich. That's an institutional change, not a cultural one.

The cultural story in China, of course, is the resurgence of the millenniaold imperial culture that Mao tried so hard to destroy during the Cultural Revolution: the culture of education. Its reemergence is testimony to the 'deep roots' of culture. But, although the veneration of hard work and education may be more than mere Prudence, it is not the market-affirming culture of early modern Holland. It was forged in a very different environment, one that was in its own way was as totalitarian as that of Mao. Although the emperors certainly did their part to discourage trade and innovation (Jones, 2003; Landes, 2006), imperial China was not a highly centralized state. Because of high communications costs, administration was mostly decentralized to a system of patronage, ideology, and power centered around a local scholar-gentry. 'The villages were self-policing', writes Jones (2003: 206), 'thus harnessing the energy of peasant envy and suspicion'. Because people were ruled by scholars, and because one of the few mechanism for bettering one's condition involved 
passing elaborate academic exams, education became an object of veneration. Yet - and this is the point - this anti-commercial culture suddenly became highly adapted to commerce in a world in which Mao had destroyed the old imperial system of administration and in which the post-Mao government had then slowly gotten out of the way.

Of course, getting out of the way is not an instantaneous disappearing act; it is an institutional process. As Coase and Wang (2012:164-165) explain, the Chinese state had hoped to plan the transition centrally, but it lost control of 'marginal' spheres of the economy like private farming, township and village enterprises, and individual entrepreneurship by unemployed urban dwellers. The central state initially tolerated these activities because they seemed peripheral and not a threat to socialism. When the peripheral economic experiments bore fruit, the state embraced them and adjusted its ideology accordingly. McCloskey tells us that well-defined property rights have long existed and thus cannot be the catalyst for growth. But in China, property rights had not existed, and creating them was an important part of the liberalization process. In a sense property rights were endogenous: they were delineated at the same time they were allocated, and, especially early on, they were partial and short-term rights subject to continual renegotiation with the state ${ }^{5}$ (Coase and Wang 2012: 171-173). What was important was that the state sanctioned the institutional experiments.

Perhaps some institutional economists do believe that delineating property rights is all that is necessary: 'add property rights and stir'. But I think the best institutional economics is far more subtle and significant. In particular, Douglass North's recent work with John Wallis and Barry Weingast (2009) is not a paean to property rights as a micro-institution but a nuanced account of the complex macro-institutional negotiation involved in getting out of the way of entrepreneurship. To put it provocatively: North, Wallis, and Weingast argue that states that have unleashed entrepreneurship - that have gotten out of the way - have done so by substituting abstract anonymous institutions for culture-rich ones. In a world with no institutions to channel entrepreneurship in productive directions, some people will seek to better their conditions by taking resources away from others, usually with violence. The most basic institutional structure in such a world is warlordism. But violence is costly, and warlords may realize eventually that they can share unexploited gains from trade if they form a coalition. This is what North, Wallis, and Weingast call a natural state. The

5 'It was peculiar, though, that China did not first delineate property rights, specify other relevant institutional rules and then allow market forces to allocate rights to the highest bidder. Instead, what rights economic actors were allowed to have, such as the discretionary rights peasants had over farmland or residual rights held by managers of state-owned enterprises, and what institutional constraints they faced in exercising their rights were delineated when the state released the rights of control to private economic actors. The delineation and transfer of rights took place in one step. ... A major advantage of combining rights delineation, and rights transaction or reallocation into one step was to speed up the introduction of market forces into the economy' (Coase and Wang 2012:173). 
natural state is a culture-based state, since it is a face-to-face society (or nearly so), in which a fragile bargain must be held together by the tacit and the interpersonal, by signaling and inexplicit negotiation, by ceremony and social sanction. The aristocratic culture of medieval and early modern Europe is a manifestation of this; so is the Confucian Mandarin system of the Chinese imperia. To keep the coalition together, the state must restrict access to trade. The kudzu must be kept neatly trimmed. But maintaining the coalition may also necessitate giving rights to members of the coalition. And as those rights slowly extend to larger classes of inhabitants, eventually an open-access order may take shape in which individuals can better their conditions without stint. ${ }^{6}$ This is effectively a deculturation of the state, and maybe of the society as well - a topic to which I return below. The state gets out of the way by substituting anonymous and impersonal institutions for institutions that had relied more heavily on tacit and nuanced culture.

In his somewhat underappreciated Paradigms and Conventions, Choi (1993) offers an account that ties together McCloskey's two arguments: the critique of Max U and the explanation of the Great Enrichment. Choi sees people not as maximizers subject to constraint but as agents adrift in a world of uncertainty. In order to make decisions, they need to make sense of the world, which they do by seeking a cognitive paradigm to provide a framework for behavior. No cognitive paradigm is an island, though, and agents have to adjust not only to the brute facts of the world but also to the behavior of others. They do this by settling upon a system of conventions, which becomes in effect a system of shared paradigms. (In economic jargon, this would be the equilibrium of a coordination game.) Within the system of conventions, agent do not maximize utility in a narrow sense but are motivated by envy and the desire to have the approval of others; in a fashion McCloskey might describe as ethical, they also seek the approval of imagined impartial spectators à la Smith.

A system of conventions is thus profoundly conservative. But it contains the seeds of its own destruction. In a changing world, conventional behavior will become misaligned with relative scarcities, throwing up potential entrepreneurial opportunities. It will be costly for agents within the conventional system to seize these opportunities, which is why entrepreneurs are often outsiders. Eventually, the magnitude of the opportunity will outstrip the costs, and the conventions will change. Especially if the entrepreneur is an insider, the changes may become part of a new system of conventions. Viewed from within this framework, McCloskey's thesis would seem to be that economic growth will take place if the system of convention (culture, ethics) makes it legitimate to take advantage of commercial entrepreneurial opportunities. (Notice that a system of conventions that legitimizes commercial activities can remain hostile to other kinds of cultural

6 Why did this happen first in northwestern Europe and not in, say, China? Arguably because Europe had many distinct states and therefore many institutional (and maybe cultural) experiments that couldn't all be vetoed by a central authority (Jones, 2003; Landes, 2006; Rosenberg and Birdzell, 1986). 
innovations, just as a system may be open to many kinds of cultural innovations while remaining hostile to commercial activities.) But getting the culture right is not the only way to lower the costs of entrepreneurship: institutions also matter. 'Of the many factors relevant in determining entrepreneurial success', writes Choi, 'most notable is the role of property rights in enabling entrepreneurs to overcome envy barriers, making possible the market process of social learning' (Choi, 1993:153). Even if the culture is against me, I have a trump card in abstract and anonymous social institutions.

It should be no surprise that this sounds more than a little Schumpeterian. I have always been a bit surprised that McCloskey has never really engaged fully with Schumpeter. Let me close by hoping that she does so in the next installment, whose theme seems to be right in Schumpeter's wheelhouse. Virtually alone among economists of the mid-20th century, Schumpeter saw the Great Enrichment as the central fact with which economics must grapple. And among only a handful of others, Schumpeter theorized about the role of culture in economic growth.

Like McCloskey, Schumpeter believed that Max U cannot explain economic growth. There was plenty of Prudence in societies without growth, 'and we can depend upon it that the peasant sells his calf just as cunningly and egotistically as the stock exchange member his portfolio of shares"7 (Schumpeter, 1934: 80). Economic growth requires Entrepreneurship. Unlike McCloskey, however, Schumpeter did not think that entrepreneurship emerges when and because culture changes to favor it. Entrepreneurship happens despite culture. Entrepreneurs are outsiders, often misfits - some of them what we would nowadays call nerds. ${ }^{8}$ What helps entrepreneurs crack the crust of convention are institutions, especially property rights broadly understood. The entrepreneur 'leads' the means of production into new channels. But this he does, not by convincing people of the desirability of carrying out his plan or by creating confidence in his leadership in the manner of a political leader - the only man he has to convince or impress is the banker who is to finance him - but by buying them or their services, and then using them as he sees fit' (Schumpeter, 1934:89).

In Schumpeter, a change in culture did not create an increase in entrepreneurship; it was an increase in entrepreneurship that created a change in culture - or, rather, a destruction of culture. The tangible success of capitalist business enlarged the institutional and cultural sphere of capitalism.

7 "This peasant 'calculates'; there is no deficiency of the 'economic way of thinking' (Wirtschaftsgesinnung) in him. Yet he cannot take a step out of the beaten path; his economy has not changed at all for centuries, except perhaps through the exercise of external force and influence. Why? Because the choice of new methods is not simply an element in the concept of rational economic action, nor a matter of course, but a distinct process which stands in need of special explanation" (Schumpeter, 1934: 80n).

8 'A genius in the business office may be, and often is, utterly unable outside of it to say boo to a goose - both in the drawing room and on the platform' (Schumpeter, 1950:). 
The institutional sphere expanded into the open-access order; the cultural sphere expanded into what Schumpeter calls a 'rationalistic' society, by which he means a society that values skepticism, common sense, and practicality over romance, magic, and heroism. Rationalistic culture gave birth to modernism, and it permeated all of artistic expression. 'The evolution of the capitalist style of life could be easily - and perhaps most tellingly - described in terms of the genesis of the modern lounge suit' (Schumpeter, 1950:126). The mid-century business suit was apparently the jeans-and-hoodie of Schumpeter's day.

Yet culture is not powerless in Schumpeter's story. Because it is so profoundly conservative, the Romantic culture of magic and heroism can serve a protection to whatever institutional structure wields it. By destroying this culture, capitalism left its 'get out of the way' institutions unprotected. At the same time, Romantic culture has an atavistic appeal, since, broadly speaking, it was the culture with which humans evolved from the time of the hunter-gatherers. For both of these reasons, the capitalist set of conventions sowed the seeds of its own destruction. It created an entrepreneurial opportunity for a New Class of intellectuals and politicians peddling magical economic thinking and heroic fiscal assumptions and who did not believe that the state should get out of the way of commercial entrepreneurship.

The world has changed considerably since Schumpeter set forth his thesis about the cultural demise of capitalism. It is time for an update from a powerful pen.

\section{References}

Baumol, W. J. (1990), 'Entrepreneurship: Productive, Unproductive, and Destructive', The Journal of Political Economy, 98(5): 893-921.

Chen, Da. (2000), Colors of the Mountain, New York: Random House.

Choi, Y. B. (1993), Paradigms and Conventions: Uncertainty, Decision Making, and Enrepreneurship, Ann Arbor: University of Michigan Press.

Coase, R. H. and Wang, N. (2012), How China Became Capitalist, New York: Palgrave Macmillan.

Greif, A. (2006), Institutions and the Path to the Modern Economy: Lessons from Medieval Trade, New York: Cambridge University Press.

Jones, E. L. (2003), The European Miracle: Environments, Economies and Geopolitics in the History of Europe and Asia, Cambridge: Cambridge University Press.

Kirzner, I. M. (1973), Competition and Entrepreneurship, Chicago: University of Chicago Press.

Landes, D. S. (2006), 'Why Europe and the West? Why Not China?', The Journal of Economic Perspectives, 20(2): 3-22.

McCloskey, D. N. (2010), Bourgeois Dignity: Why Economics Can't Explain the Modern World, Chicago: University of Chicago Press.

McCloskey, D. N. (2015), 'Max U Versus Humanomics: A Critique of Neoinstitutionalism', Journal of Institutional Economics, published online. DOI: 10.1017/S1744137415000053. 
North, D. C. (2005), Understanding the Process of Economic Change, Princeton: Princeton University Press.

North, D. C., J. J. Wallis and B. R. Weingast (2009), Violence and Social Orders: A Conceptual Framework for Interpreting Recorded Human History, New York: Cambridge University Press.

Polanyi, K. (1944), The Great Transformation: The Political and Economic Origins of Our Time, New York: Farrar \& Rinehart.

Robbins, L. (1932), An Essay on the Nature and Significance of Economic Science, London: Macmillan.

Rosenberg, N. and Birdzell, L. E., Jr. (1986), How the West Grew Rich, New York: Basic Books.

Schumpeter, J. A. (1934), The Theory of Economic Development, Cambridge: Harvard University Press.

Schumpeter, J. A. (1950), Capitalism, Socialism, and Democracy, New York: Harper and Brothers.

Smith, A. (1976), An Enquiry into the Nature and Causes of the Wealth of Nations, Oxford: Clarendon Press. 